\title{
PENYEMBUHAN PENYAKIT: SEBUAH STUDI EKSEGETIS BERDASARKAN MARKUS 16:17-18
}

Made Nopen Supriadi

madenopensupriadi@sttab.ac.id

\begin{abstract}
The Lord Jesus before ascending to Heaven did say there would be signs accompanying believers, one of which was that they laid their hands on the sick, and the person was healed. Some groups really claim that every believer can cure a disease, is that right? To answer this question, it is very necessary to discuss Mark 16: 17-18. In this discussion using the Historical Redemptive method (redemptive history). So that through discussion with the History of the Atonement method you can understand the meaning of the text in the context of the History of the Atonement.
\end{abstract}

Keywords: $\quad$ Healing, Disease, Exegetical Study.

Abstraksi: $\quad$ Tuhan Yesus sebelum naik ke Surga memang menyatakan akan ada tandatanda yang menyertai orang percaya, salah satunya ialah mereka meletakan tangannya atas orang sakit, dan orang itu sembuh. Beberapa kelompok sungguh-sungguh mengklaim bahwa stiap orang percaya yang dapat menyembuhkan penyakit, benarkah demikian? Untuk menjawab pertanyaan demikian maka sangat perlu membahas Markus 16: 17-18. Dalam pembahasan ini memakai metode Historical Redemptive (sejarah penebusan). Sehingga melalui pembahasan dengan metode Sejarah Penebusan dapat mengerti arti teks dalam konteks Sejarah Penebusan."

Kata Kunci: Penyembuhan, Penyakit, Studi Eksegetis.

\section{PENDAHULUAN}

Studi Alkitab merupakan bagian penting untuk memahami teks-teks Alkitab secara komprehensif. Hal tersebut sesuai dengan slogan para reformator yang menekankan prinsip sola scriptura. ${ }^{1}$ Oleh karena itu prinsip sui ipsius interpretes(Alkitab Menafsirkan Alkitab)merupakan prinsip penting dalam mengerti teks-teks Alkitab. Salah satu metode dalam menjelaskan teks-teks Alkitab yaitu dengan metode Redemptive Historical (Sejarah Penebusan). Philip Johnston setuju jika tema yang paling tepat untuk teologi Alkitab ialah mengenai sejarah keselamatan, ia menuliskan:

"Penulis-penulis Alkitab PB menerima latar belakang A;litab PL itu dan mengumumkan bahwa kedatangan Yesus Sang Mesias, Allah telah meresmikan penebusan dan pembaharuan yang sudah final. Melalui kehidupan, kematian dan kebangkitan Yesus, penghukuman atas umat manusia sudah dibalikkan dan kebangkitan zaman akhir telah dimulai.

\footnotetext{
${ }^{1}$ Sola Scriptura ialah percaya kepada apa yang dikatakan oleh Alkitab yang adalah firman Tuhan. Stephen Tong, Reformasi dan Theologi Reformed (Jakarta: LRII, 1999), 27
} 


\begin{abstract}
Allah sekarang menciptakan suatu umat Allah yang baru -gereja- yang misinya ialah untuk memproklamirkan berita keselamatan kepada seluruh dunia.",
\end{abstract}

Penggunaan metode sejarah penebusan dalam memaknai silsilah di Kitab Kejadian dan mengenai perjanjian telah dilakukan oleh Pdt. Abraham Park, D.Min, D.D dalam ke-4 jilid bukunya. Beliau menuliskan bahwa "semua sejarah yang terbentangkan di bumi ini dijalankan dengan berpusatkan pada Yesus Kristus, digenapi melalui Yesus Kristus, dan akan disempurnakan melalui kedatangan Yesus Kristus Kembali”. ${ }^{3}$ Oleh karena itu salah satu metode untuk menjawab mengenai teks Markus 16:17-18 secara khusus mengenai apakah setiap orang percaya dapat menyembuhkan penyakit akan dilihat dalam konteks berpikir sejarah penebusan.

\title{
METODOLOGI
}

Metodologi yang digunakan dalam menuliskan artikel ini adalah metode kualitatif. ${ }^{4}$ Sehingga hanya berfokus pada kajian hasil dari sebuah pemahaman terhadap teks. Dalam menuliskan materi juga melakukan kajian Bibliogis. Kajian tersebut didasarkan pada sumber utama yaitu Alkitab disertai dengan berbagai buku refrensi yang mendukung melakukan pengkajian eksegetikal. Pada bagian akhir akan memberikan kesimpulan terhadap kajian teks yang telah dilakukan.

\section{LATAR BELAKANG KITAB MARKUS}

Sebelum membahas Markus 16:17-18 maka perlu bagi kita untuk melihat latar belakang Kitab tersebut. Pertama mengenai penulis Kitab Markus ialah Markus yang disebut dalam Kisah Para Rasul 12: 12, dia adalah murid Petrus (1Petrus 5: 13). Kepenulisan Markus tersebut juga mendapat dukungan dari Bapa-Bapa Gereja. ${ }^{5}$ Lalu selanjutnya mengenai

\footnotetext{
${ }^{2}$ Philip Johnston, IVP Introduction To The Bible, (Bandung: Kalam Hidup, 2011), 267

${ }^{3}$ Abraham Park, Silsilah DI KItab Kejadian (Jakarta: PT. Gramedia Widiasaranan Indonesia, 2013), 31

${ }^{4}$ Penelitian kualitatif sebagai: Any investigation which does not make use of statistical procedures is called "qualitative" nowdays, as if this were a quality label in itself. Definisi tersebut, menekankan pada ketidakhadiran penggunaan alat-alat statistik dalam penelitian kualitatif. Hal ini tentunya untuk mempermudah dalam membedakan penggunaan metode kualitatif dengan penggunaan metode kuantitatif. Karena metode kuantitatif bergantung pada penggunaan perhitungan dan prosedur analisis statistika. Sementara itu, metode kualitatif lebih menekankan pada pengamatan fenomena dan lebih meneliti ke subtansi makna dari fenomena tersebut. Analisis dan ketajaman penelitian kualitatif sangat terpengaruh pada kekuatan kata dan kalimat yang digunakan. Oleh karena itu,fokus dari penelitian kualitatif adalah pada prosesnya dan pemaknaan hasilnya. Anwar Hidayat, Memahmai Metode Penelitian Kualitatif, Artikel DJKN. (2012/10/14). https://www.djkn.kemenkeu.go.id/artikel/baca/12773/Memahami-Metode-Penelitian-Kualitatif.html, diakses 2018/01/25)

${ }^{5}$ Kesaksian yang penting jelas dari tokoh-tokoh gereja mula-mula terdapat dalam tulisan Papias. Dia
} 
keotentikan teks Markus 16:9-20. Donald Guthrie menuliskan bahwa ada 8 naskah yang menunjukkan bahwa Markus diakhiri pada pasal 16:8. ${ }^{6}$ Ola Tulluan juga memberi tanggapan terhadap keraguan teks Marus 16:9-20 sebagai berikut: "kita cukup menjawab bahwa bagaian terakhir ini juga diakui sebagai Firman Tuhan oleh gereja mula-mula, itu berarti janji Tuhan dalam Markus 16:18 masih tetap berlaku". ${ }^{7}$ Jawaban dari Ola Tulluan memberikan dua anggapan, yaitu: Teks Markus 16:9-20 adalah firman Allah dan apa yang tertulis dalam Markus 16:18 salah satunya mengenai penyembuhan orang sakit oleh orang percaya juga masih berlaku sampai sekarang. Untuk menjawab hal tersebut maka perlu dilakukan analisa konteks teks.

\section{Konteks Teks Markus 16:17-18}

Markus 16:17-18 merupakan perkataan dari Tuhan Yesus Kristus kepada kesebelas murid Tuhan Yesus. Tuhan Yesus mengatakan hal tersebut setelah Dia menampakan diri kepada para Murid (ay. 14) dan sebelum Dia terangkat ke Sorga (ay.19). Ayat 17-18 masuk dalam bagian perkataan Yesus yang dimulai dari ayat 15. Ini bias juga disebut sebagai pesan terakhir Tuhan Yesus kepada para Murid. Beberapa pesannya ialah: Pergi untuk memberitakan Injil dan pemberian kuasa melalui tanda-tanda dalam pemberitaan Injil. Oleh karena itu sangat jelas bahwa konteks ayat 17-18 menunjuk pada tanda-tanda dalam pemberitaan Injil yang dilakukan oleh para Murid. Mengenai hal tersebut Graham Swift menuliskan bahwa contoh-contoh segala tanda ini dapat ditemukan dalam PB, kecuali hal minum racun. Lihat Kisah Para Rasul 8: 7, 2: 4, 28: 3-5, 28:8. ${ }^{8}$

Menulis: "Markus-juru bahasa Petrus- mencatat dengan teliti, walaupun tidak memperhatikan urutan-urutan peristiwa itu. Dia menulis sesuai dengan ingatannya karena dia tidak pernah mendengar Yesus atau bertemu dengan Dia. Tetapi dia dididik di bawah pimpinan Petrus. Oleh karena itu benar semua yang ditulis oleh Markus. Segala sesuatu ditulis dengan teliti dan dia berusaha untuk tidak melupakan sedikitpun dari apa yang didengarnya". Lalu selanjutnya pernyataan Kelemens dari Alexandria: "Injil yang kedua itu ditulis oleh Markus atas dorongan dan keinginan para pendengar Petrus di Kota Roma". Ola Tulluan, Introduksi Perjanjian Baru, (Batu: Departement Literatur YPPII, 1999), 41

${ }^{6}$ Naskah-naskah tersebut ialah 1). Dua manuskrip Uncial Alexandrian: Vaticanus dan Sinaiticus, berakhir dengan efobounto gap (16:8). 2). Naskah Kuno Sinaitik juga tidak mencatat 16:9-20. 3). Sebagian besar manuskrip Armenian berakhir di 16:8. 4). Beberapa manuskrip memiliki dua akhiran ay. 9-20 dan akhiran yang lebih singkat (Sahidik, Etiopik, Harklean Siriak dan versi Bohairik terawal). 5). Semua manuskrip "k" yang berasal dari Latin Kuno berakhir di 16:8. 6). Satu manuskrip, Codex W, memiliki akhiran jenis ketiga, yaitu terdiri dari ayat 9-20, ditambah sisipan setlah ayat 14. 7). Eusebius dari Kaisarea mengutip seorang pembela iman yang menyinggung tentang "salinan tidak akurat" dari Injil Markus untuk melawan keaslian 16:9-20. 8). Manuskrip Armenian dari abad X memberikan catatan antara 16:8 dan ayat setelahnya, yang berbunyi: "dari penatua Aristion”. Donald Guthrie, Pengantar Perjanjian Baru Vol. 1 (Surabaya: Momentum, 2010), 69

${ }^{7}$ Ola Tulluan, Introduksi...., 45

${ }^{8}$ C. E. Graham Swift, Tafsiran Alkitab Masa Kini (Jakarta: YKBK, 1994), 184 


\section{PEMBAHASAN TEKS MARKUS 16: 17-18}

Dalam Terjemahan Baru (TB) Indonesia menuliskan Markus 16:17-18 sebagai berikut: "Tanda-tanda ini akan menyertai orang-orang yang percaya: mereka akan mengusir setan-setan demi nama-Ku, mereka akan berbicara dalam bahasa-bahasa yang baru bagi mereka, mereka akan memegang ular, dan sekalipun mereka meminum racun maut, mereka tidak akan mendapat celaka, mereka akan meletakkan tangannya atas orang sakit, dan orang itu akan sembuh". Kalimat penting yang perlu untuk di mengerti ialah "tanda-tanda ini akan menyertai orang-orang yang percaya" dan "mereka akan meletakkan tangannya atas orang sakit, dan orang itu akan sembuh".

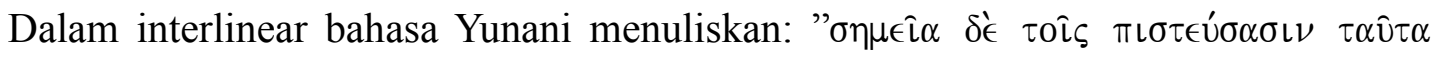

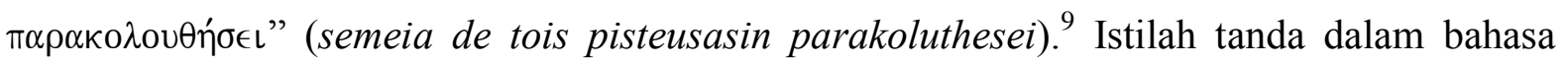
Yunani ditulis dengan kata " $\sigma \eta \mu \epsilon \hat{\imath} \alpha$ (semeia)" kata ini merupakan kata benda, nominatif,

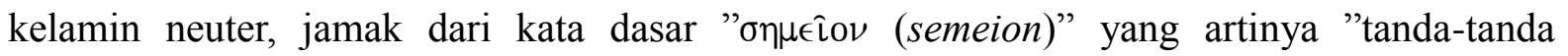
(peringatan), tanda (ajaib), tanda (heran), tanda (hebat), tanda (mengerikan) ". ${ }^{10}$ Selanjutnya istilah "orang percaya" dalam bahasa Yunani "tois pisteusasin" menggunakan bentuk aktif partisip dari kata dasar "pisteuo", jadi istilah tersebut menunjukkan para murid bukan hanya sekedar percaya tetapi ada partisipasi keaktifan dalam tindakan beriman mereka. Thomas Hale memberikan pandangan bahwa tanda -tanda tersebut membedakan orang Kristen dengan orang lain, namun tidak dimaksudkan untuk semua orang Kristen melainkan orang tertentu, karena masing-masing orang percaya diberikan karunia tertentu sesuai dengan kehendak Roh Kudus seperti yang tertulis dalam 1 Korintus 12:7-11. ${ }^{11}$ Jadi tanda-tanda tersebut pasti ada dalam kehidupan orang percaya, namun bukan karena dibuat-buat oleh orang percaya namun karena karunia Roh Kudus. Hal tersebut menunjukkan bahwa karunia menyembuhkan juga ada diberikan bagi orang percaya tetepi tidak semua orang percaya mutlak bisa menyembuhkan. Mengenai hal tersebut Matthew Henry menuliskan :

"Tidak semua orang percaya mampu membuat tanda-tanda ini, melainkan hanya beberapa terutama mereka yang menyebarkan mengenai iman ini dan membawa orang lain kepada iman itu. Sebab tanda-tanda ini ditujukan

\footnotetext{
LAI, 2012), 290

${ }^{10}$ Hasan Sutanto, Perjanjian Baru Interlinear Yunani - Indonesia dan Konkordansi Jilid II (Jakarta: LAI, 2012), 704

${ }^{11}$ Thomas Hale, The Applied New Testament Commentary (England: Kingsway Publications, 1996),
}

${ }^{9}$ Hasan Sutanto, Perjanjian Baru Interlinear Yunani - Indonesia dan Konkordansi Jilid I (Jakarta: 
kepada orang yang tidak percaya (1Kor. 14:22). Kemuliaan dan bukti kebenaran Injil akan sangat bertambah jika para pemberitannya bukan saja bisa mengadakan mujizat itu sendiri, tetapi bisa meneruskan kuasa tersebut kepada orang lain untuk melakukanmujizat." 12

Selanjutnya ada kalimat " mereka akan meletakkan tangannya atas orang sakit, dan orang itu akan sembuh”. Dalam Alkitab Edisi Studi menuliskan komentar mengenai ayat 18 demikian:

\begin{abstract}
"Meletakkan tangannya atas orang sakit, dan orang itu akan sembuh; Yesus biasanya menyentuh orang yang sakit ketika hendak menyembuhkannya. Pada masa gereja perdana, mengoleskan minyak pada orang sakit adalah salah satu bagian yang penting dalam suatu upacara penyembuhan (Lih. Yak. 5: 14)."13
\end{abstract}

Jadi ada tradisi pengobatan pada masa itu juga terhadap sebuah penyakit yaitu dengan mengoleskan minyak. Hal tersebut menunjukkan sebuah perkembangan metode, jika Tuhan Yesus menyembuhkan hanya dengan menyentuhkan tangan atau menumpangkan tangan, maka lambat laut hal tersebut mulai digantikan dengan metode pengolesan minyak. Maka terlihat ada progresifitas penyembuhan, dari mujizat menuju hikmat. Selanjutnya lebih jauh mengenai ungkapan meletakkan tangan dan menjadi sembuh Matthew Henry memberikan komentar demikian:

"Mereka bukan saja dipelihara dari celaka itu sendiri, namun juga diberi kemampuan berbuat baik kepada orang lain. Banyak penatua jemaat yang memiliki kuasa ini. Seperti tampak dalam Yakobus 5: 14. Di mana sebagai tanda untuk melakukan kesembuhan yang ajaib ini, mereka dikatakan harus mengoles sisakit dengan minyak dalam nama Tuhan." 14

Motif penyembuhan pada masa jemaat mula-mula sebagai wujud perhatian bagi sesama mereka yang belum percaya. Donald W. Burdick memberikan komentar mengenai ayat 17 dan 18 demikian:

pernyataan tentang pengusiran setan dab berbicara dalam bahasa yang baru (ay. 17) sangat mungkin mengacu kepada berbagai peristiwa di gereja mula-mula sebagaimana yang tercatat di dalam Kitab Kisah Para Rasul. Bahkan kata-kata tentang memegang ular mungkin merupakan petunjuk untuk pengalaman Paulus dalam Kisah Para Rasul 28:1-6. Tidak ada ayat lain dalam PB yang membahas tentang minum racun. Meskipun bagian ini sepenuhnya asli, ayat-ayat ini tidak dapat dipakai secara sembarangan sehingga dengan sengaja dan lancang memegang ular dan meminum racun

\footnotetext{
${ }^{12}$ Matthew Henry, Kitab Markus (Surabaya: Momentum, 2015), 398

${ }^{13}$-------, Alkitab Edisi Studi (Jakarta: LAI, 2012),1657

${ }^{14}$ Matthew Henry, Kitab...., 398
} 
seperti yang dilakukan beberapa golongan agama ekstrem."

Pernyataan tersebut semakin menunjukkan bahwa tanda-tanda tersebut hanya karena karunia Roh Kudus. Manusia sekalipun percaya Tuhan Yesus namun jika tidak dikaruniakan maka manusia tersebut tidak boleh juga mencobai Tuhan. Oleh karena itu perlu dipahami bahwa jika karunia menyembuhkan tidak terdapat dalam jemaat yang percaya kepada Tuhan Yesus, maka pastilah Tuhan telah memperlengkapi jemaat tersebut dengan hikmat penyembuhan. Mujizat bukannya tiada namun Tuhan dapat bekerja mendatangkan mujizat kesembuhan dengan memberikan dan mengembangkan hikmat manusia untuk mengatasi penyakit yang ada.

\section{KESIMPULAN}

Gereja Tuhan yang baru berkembang membutuhkan tanda-tanda tersebut namun tidak setiap Murid Tuhan Yesus secara personal dapat melakukan semua tanda tersebut. Mujizat penyembuhan diberikan Allah sebagai upaya menopang pelayanan penginjilan para Murid kepada orang tidak percaya sehingga Injil semakin diteguhkan. Namun tanda-tanda tersebut tidak akan serta merta terlihat lagi dalam perkembangan gereja selanjutnya oleh karena Allah telah membukakan hikmat bagi manusia dan orang percaya. Jadi jika merlihat dalam konteks sejarah penebusan, tanda-tanda yang menyertai orang percaya tetap ada Tuhan tidak mentiadakannya, namun Tuhan bisa mengalihkannya dengan membuka pikiran manusia untuk mengerti hikmat menyembuhkan. Namun jika hikmat manusia tidak sanggup mengatasi penyakit tersebut maka Tuhan bisa menggerakkan iman orang percaya untuk melakukan tanda kesembuhan oleh karena didorong rasa mengasihi sesama. Tindakan melakukan penyembuhan ini bukanlah juga sebagai sikap mencobai Tuhan, dengan melawan fakta yang jelas sudah nyata. Artinya jika sudah divonis sakit dan penyakit tersebut bisa diobatai namun obat yang digunakan sangat mahal, bukan berarti serta merta mujizat terjadi atau orang percaya mulai memanjatkan doa-doa yang cenderung memakasa Tuhan, atau memakasa pengalaman dalam Kisah Para Rasul kembali terjadi dalam konteks masa kini. Orang percaya harus mulai memikirkan hikmat dari Tuhan bagaimana mendapatkan obat yang mahal, maka disitulah juga cara Tuhan bekerja membimbing orang percaya untuk mengatasi sebuah penyakit. Namun hal ini semakin menegaskan bahwa ada masa di mana sakit-penyakit tiada dan manusia hidup kebahagiaan kekal. Dan keadaan tersebut hanya akan terjadi pada saat kedatangan Tuhan Yesus yang kedua kali.

\footnotetext{
${ }^{15}$ Donald W. Burdick, The Wycliffe Bible Commentary (Malang: Gandum Mas,2008 ), 210
} 


\section{DAFTAR PUSTAKA}

-------. (2012). Alkitab Edisi Studi, Jakarta: LAI.

E. Graham Swift, C. (1994). Tafsiran Alkitab Masa Kini , Jakarta: YKBK.

Guthrie, Donald. (2010). Pengantar Perjanjian Baru Vol. 1, Surabaya: Momentum.

Hale, Thomas. (1996). The Applied New Testament Commentary, England: Kingsway Publications.

Henry, Matthew. (2015). Kitab Markus, Surabaya: Momentum.

Johnston,Philip. (2011). IVP Introduction To The Bible, Bandung: Kalam Hidup. Park, Abraham. (2013). Silsilah Di Kitab Kejadian, Jakarta: PT. Gramedia Widiasaranan Indonesia.

Stephen Tong (1999). Reformasi dan Theologi Reformed, Jakarta: LRII.

Sutanto, Hasan. (2012).Perjanjian Baru Interlinear Yunani - Indonesia dan Konkordansi Jilid I, Jakarta: LAI.

(2012) Perjanjian Baru Interlinear Yunani - Indonesia dan Konkordansi Jilid II, Jakarta: LAI.

Tulluan, Ola. (1989). Introduksi Perjanjian Baru, Batu: Departement Literatur YPPII.

W. Burdick, Donald. (2008). The Wycliffe Bible Commentary, Malang: Gandum Mas. 